\title{
Adaptive capacity of water governance arrangements: a comparative study of barriers and opportunities in Swiss and US states
}

\author{
Margot Hill Clarvis $\cdot$ Nathan L. Engle
}

Received: 11 April 2013/Accepted: 26 October 2013/Published online: 19 November 2013

(C) Springer-Verlag Berlin Heidelberg 2013

\begin{abstract}
Climate variability and change are directly challenging the viability and sustainability of social-ecological systems. This is particularly true for water resources. Effective water governance is at the heart of alleviating water challenges and is thus considered crucial for building adaptive capacity to cope with future uncertainty and impacts from climate change. Despite advances in the conceptualisation of adaptive capacity, there are few empirical examples that look systematically across cases to identify how to implement measures and actions that build and mobilise adaptive capacity. This paper contributes to the understanding of adaptive capacity to climate stress by analysing the bridges and barriers to adaptation across water governance and management regimes in the case of the Canton Valais, Switzerland and the state of Georgia, USA. We find that while there is no single way to build and mobilise adaptive capacity across different scales of governance, the analysis points to a set of common bridges and barriers for building adaptive capacity to a variety of climatic events. Common bridges include trust and actor relationships, regional collaboration, leadership, and
\end{abstract}

Electronic supplementary material The online version of this article (doi:10.1007/s10113-013-0547-y) contains supplementary material, which is available to authorized users.

M. Hill Clarvis $(\bowtie)$

Institute of Environmental Sciences, University of Geneva,

Site de Battelle D, Rue du Drize 7, 1227 Carouge,

Geneva, Switzerland

e-mail: margot.hill@unige.ch

N. L. Engle

2011-2012 AAAS Science and Technology Policy Fellow, American Association for the Advancement of Science (AAAS),

Washington, DC, USA

e-mail: nlengle@gmail.com regulatory and legislative aspects. Common barriers include political, regulatory and legislative, and perception and cognitive aspects.

Keywords Climate change - Adaptive capacity · Water governance $\cdot$ USA $\cdot$ Switzerland

\section{Introduction}

Water resources are crucial to every facet of ecological, economic and social systems. Water governance [(the encompassing institutions, broader laws, regulations, policies, actions and actor networks with which water resources are managed) (UNDP 1997)] and management are critical to ensuring that these systems equitably achieve multi-sector water requirements, as well as acceptable water quality standards and availability in the face of hydroclimatic events and climate change impacts (Folke et al. 2005). Moreover, governance and the associated institutions and management approaches are key in facilitating and mobilising effective adaptations, thereby increasing or decreasing adaptive capacity (Adger et al. 2005).

Despite this basic understanding of the importance of governance for effective adaptation decision-making, there remains relatively little empirical examination into the forms of governance approaches that most positively influence adaptive capacity (Medema et al. 2008). In this paper, we present empirical evidence from studies into the adaptive capacity of water governance and management in the canton (i.e. state) of Valais (Switzerland) and the state of Georgia (USA). The cases investigate different governance-related bridges and barriers affecting adaptations with respect to recent extreme climatic events. The cases therefore offer an empirical analysis of the governance 
factors that can help or hinder the development and mobilisation of adaptive capacity.

While the cases are diverse in the type of climate stress experienced and population affected, they both represent federal governance systems (where each level of government has sovereignty in some areas and shares powers in other areas) with similar challenges of scale. Analysis uncovers a number of common bridges and barriers upon which decision-makers might focus on building and mobilising adaptive capacity across scales of water governance.

\section{Background}

Adaptation to climate change in water governance and management

Researchers have criticised traditional water governance and management approaches as being dominated by a command and control paradigm and fragmented regulatory and institutional landscapes that do not take the complex inter-linkages of the social-ecological systems (SESs) into account, instead seeking to eliminate uncertainty rather than attempt to manage and live with it (Pahl-Wostl et al. 2009). For example, ministries, agencies and regulation are often siloed along sectoral lines, while rule-making on water resources may not take into account the needs, challenges and reality at the local level. Furthermore, traditional management approaches have favoured the control of the hydrological cycle (i.e. dam construction, dyke enforcement) in order to reduce natural threats and produce more predictable outcomes (Jewitt 2002).

Governance is recognised as being critical for building and mobilising adaptive capacity (Brooks and Adger 2005; Engle and Lemos 2010). It relates to the different processes of making and setting rules and institutions and takes into account the different actors and networks that negotiate positions in balancing trade-offs in policy and its instruments (Pahl-Wostl 2009). To manage normal ranges of uncertainty (e.g. inter-annual variability of climate leading to sequences of wet and dry years, stochastic or internal climate variability), a water governance system might have prioritisation rules that kick in when indicators suggest a dry year is underway. More specifically, water management is concerned with the application of these rules and operationalisation of the policy visions with the practical aspects of water allocation, protection and prevention of harm from extremes (Folke et al. 2005; Pahl-Wostl 2009). Many current water supply management adaptation techniques thus relate to reservoir storage to tie over water provision during dry years, while often flood management strategies relate to techniques such as dykes and early warning systems that protect against high precipitation events (Smit and Wandel 2006).

However, climate change embodies a more unpredictable form of uncertainty or 'non-stationarity' (reduced runoff contribution from glacier and snow melt, shifts in seasonality, increasingly consecutive dry years) that may lie beyond the coping ranges of past and present water management and governance regimes (Matthews et al. 2011; Milly et al. 2008). To meet these challenges, climate change and water governance and management research communities have in recent years focussed more heavily on better understanding adaptive processes (Pahl-Wostl et al. 2007).

Understanding and fostering adaptive capacity

Adaptive capacity is the ability of actors, individuals and groups to prepare for, respond to, create and shape variability and change in a system (Chapin et al. 2009b). It can be characterised by preconditions necessary to enable adaptation, including social and physical elements, and the ability to mobilise these elements (Nelson et al. 2007). Across the broad determinants of adaptive capacity, there has been wide recognition of the critical role of institutions and governance mechanisms in setting effective rules and incentives for adaptive and sustainable water use and protection at local, regional and national levels (Adger et al. 2005; Nelson et al. 2007).

There are numerous ways that researchers have assessed adaptive capacity (Engle 2011), but, to date, many studies begin with the assumption that certain governance arrangements (i.e. frameworks or settings) or principles are desirable or key to increasing adaptive capacity (e.g. integrated water resources management and adaptive management) (Brooks et al. 2005; Pahl-Wostl et al. 2007; Tompkins et al. 2008) and in turn, evaluate the presence or absence of these arrangements and principles as indicators of adaptive capacity. In the past decade, numerous studies have developed a deeper understanding of relevant institutional and governance indicators of adaptive capacity in different social-ecological systems (Engle and Lemos 2010; Folke et al. 2005; Gupta et al. 2010). Specifically, these different studies have highlighted the importance of governance indicators such as information and knowledge, experience and expertise, networks, transparency, trust, commitment, leadership, legitimacy, accountability, connectivity and collaboration, iterativity, flexibility and leadership.

Likewise, the associated literatures on resilience (the ability to absorb disturbance while retaining the same fundamental system structure, function and identity) (Chapin et al. 2009a) and disaster risk resilience/reduction (DRR) also stress the importance of iterative (e.g. 
integrating best available climate science), flexible approaches (Garmestani et al. 2009; Huntjens et al. 2011) in both governance and management as well as in integrative (Gaillard and Mercer 2013), multi-level institutional arrangements (Seng 2013) and community-based adaptations (Adhikari and Taylor 2012). Namely, multilevel and sector approaches should ensure that short-term adaptation or preparatory actions to certain hazards or risks do not undermine the ability of that system to respond to other stressors (Adger et al. 2011). Adaptive capacity should therefore contribute to enhancing resilience, rather than leading to adaptations that degrade resilience.

However, less research has investigated deeper empirical examples of adaptive actions and measured the role of governance arrangements in climate-stress periods (Folke et al. 2005; Pahl-Wostl 2007). This study uses recent past extreme events as a proxy for future climate change conditions to empirically evaluate the governance arrangements in each case area (Adger et al. 2007; Folke et al. 2005). This enables us to identify actual manifestations of adaptive capacity (i.e. adaptive actions) in order to better understand the role that different governance approaches play in building adaptive capacity.

\section{Bridges and barriers to adaptation}

Barriers to adaptation are recognised as persisting at local, regional and national scales and represent impediments that can delay or momentarily block the adaptation process (Ekstrom et al. 2011). Recent studies have highlighted a number of common barriers to adaptation processes, including challenges in uncertainty and fragmentation of decision-making and information on climate change, lack of resources and leadership, fragmented decision-making and institutional challenges as well as contrasting risk perceptions and values (Bierbaum et al. 2012; Ekstrom et al. 2011; Moser and Eckstrom 2010).

While indicators of adaptive capacity may be framed as bridges in some studies, negative fulfilment of these indicators may be seen as barriers, thereby identifying what can hinder actors at different temporal stages of the adaptation process (Moser and Eckstrom 2010) or at different spatial scales of adaptation (local, regional and national) (Crabbé and Robin 2006). A difference in framing specific issues such as 'bridges' or 'barriers' rather than 'indicators' is that it allows a more nuanced identification of specific lever points that water managers and policy makers could capitalise on to implement targeted interventions that develop more adaptive responses to hydroclimatic stresses. Therefore, the investigation of bridges and barriers in relation to a set of governance-related adaptive capacity indicators enables the researcher to identify key water governance mechanisms and factors that are most commonly influencing adaptive capacity in practice across the individual cases.

\section{Case areas and methodology}

The evidence that this article presents and explores comes from two independent studies conducted in Switzerland (2010-2011) and the USA (2009-2010). Each case study (see Table 1) represents an assessment of adaptive capacity in water governance arrangements to climate variability and change impacts.

The studies use a similar body of governance-related indicators to explore adaptive capacity in relation to past extreme hydrological events (Engle 2011; Hill 2011). To ensure compatibility and comparability across the different case areas, a process of comparing and consolidating project frameworks, methodological and analytical developments was initiated in the development phases of the independent studies. This first collaborative step ensures consistency across the definitions of the indicators and criteria and thus enables a comparison of the key findings in order to develop common conclusions across the independent studies. The motivation for pursuing similar methodologies between the two studies is that it represents an important contribution to generating research on adaptive capacity to overcome the challenges of scaling up adaptation research. Thus, despite the different contexts, generating common lessons from contrasting systems is vital for scaling up local lessons so that they can be applied across different contexts (Smit and Wandel 2006).

The governance indicators utilised in the studies are drawn from the adaptive governance, adaptive management and integrated water resources management literature (Folke et al. 2005; Nelson et al. 2007; Pahl-Wostl 2007) as discussed in 'Understanding and Fostering Adaptive Capacity' section. The indicators are grouped into the following categories: networks, flexibility, knowledge and integration (see Table 2). The studies employ past climatic events as the primary context through which to explore adaptive behaviour in relation to the indicators. Figure 1 shows the conceptual framework applied in this paper.

In-depth semi-structured interviews with stakeholders and experts (water managers, water users, government representatives, NGOs, scientists and academic experts) across local, regional and national governance scales $(N=45)$ provide qualitative data on planning and preparation for hydrological extremes, coping mechanisms and adaptation actions before, during and after the events. In addition to the interviews, the studies also analyse archival data on the relevant policy, planning, legislative and regulatory framework. The data are then analysed and coded to identify which structures, relationships, processes and 
Table 1 Background to the case areas

\begin{tabular}{|c|c|c|c|c|}
\hline Case study & Climate & System stressors & Governance context & Focussing events \\
\hline $\begin{array}{l}\text { Canton } \\
\text { Valais, } \\
\text { Switzerland }\end{array}$ & $\begin{array}{l}\text { Mediterranean } \\
\text { climate, Nivo- } \\
\text { Pluvial regime (high } \\
\text { run-off in summer } \\
\text { and low run-off in } \\
\text { winter) }\end{array}$ & $\begin{array}{l}\text { Large concentration of } \\
\text { hydropower production leading } \\
\text { to inter-sector management } \\
\text { challenges. Ski and tourism } \\
\text { area generating seasonal peaks }\end{array}$ & $\begin{array}{l}\text { Decentralised country, with } \\
\text { federal and cantonal laws on } \\
\text { water use, protection and water } \\
\text { course management. } \\
\text { Communes (municipalities) are } \\
\text { the functional entities for water } \\
\text { management. Mixture of } \\
\text { public, private and common } \\
\text { property rights for water } \\
\text { resources. In Canton (state) } \\
\text { Valais, the communes are the } \\
\text { main water rights holders for } \\
\text { the tributaries to the Rhône, } \\
\text { while the Canton is the owner } \\
\text { of water rights of the Rhône } \\
\text { itself }\end{array}$ & $\begin{array}{l}\text { Flooding events ( } 1993 \& 2000) \\
\text { and seasonal peaks and } \\
\text { scarcity; rain shadow causes } \\
\text { highly variable precipitation } \\
\text { at different elevations. } \\
\text { Recession of glaciers, } \\
\text { changes in seasonality, } \\
\text { melting of permafrost, and } \\
\text { changes in vegetation and } \\
\text { precipitation. Periods of low } \\
\text { precipitation have, however, } \\
\text { so far been offset with } \\
\text { increased glacier meltwater }\end{array}$ \\
\hline $\begin{array}{l}\text { Georgia, } \\
\text { USA }\end{array}$ & $\begin{array}{l}\text { Humid/subtropical } \\
\text { climate }\end{array}$ & $\begin{array}{l}\text { Rapid population growth over } \\
\text { the past several decades, and a } \\
\text { similar local deference to } \\
\text { economic growth as in the } \\
\text { Arizona case }\end{array}$ & $\begin{array}{l}\text { Uses a 'regulated riparian' } \\
\text { approach, meaning that those } \\
\text { having land ownership adjacent } \\
\text { to a stream have water rights, } \\
\text { but must receive a permit from } \\
\text { the state before withdrawing } \\
\text { the water }{ }^{\text {a }} \text { CWS is also } \\
\text { important in Georgia for } \\
\text { maintaining lifestyles and } \\
\text { livelihoods, and meeting basic } \\
\text { human needs, while also } \\
\text { playing a critical role in the } \\
\text { vitality of SES }\end{array}$ & $\begin{array}{l}\text { Recent multi-year droughts } \\
\text { (weakly attributable to La } \\
\text { Niña) have occurred in this } \\
\text { region, most prominently } \\
\text { from } 2006 \text { to } 2008 \text {. } \\
\text { Historically abundant rainfall } \\
\text { levels (well above the amount } \\
\text { needed to sustain human and } \\
\text { ecosystem needs) challenge } \\
\text { water supplies during the } \\
\text { droughts, with water } \\
\text { availability and drought } \\
\text { issues often interacting with } \\
\text { flooding and growth issues }\end{array}$ \\
\hline
\end{tabular}

a Those using water above an average of 100,000 gallons/day each month are required to have a permit (Wright 1998)

Table 2 Overview of Governance Indicators of Adaptive Capacity

\begin{tabular}{|c|c|}
\hline $\begin{array}{l}\text { Indicator } \\
\text { category }\end{array}$ & Criteria \\
\hline Networks & $\begin{array}{l}\text { Connectivity between groups and stakeholders that } \\
\text { allow common and integrated solutions to be } \\
\text { negotiated; willingness to cooperate during } \\
\text { extreme climate stress }\end{array}$ \\
\hline Flexibility & $\begin{array}{l}\text { Accessible, expedient and effective conflict } \\
\text { resolution mechanisms; emergency mechanisms, } \\
\text { provisions and equitable prioritizations }\end{array}$ \\
\hline Knowledge & $\begin{array}{l}\text { Available, accessible and current information for } \\
\text { informing adaptation decision-making; effective } \\
\text { monitoring and observation; usability of data for } \\
\text { accurate decision-making; multiple timescales at } \\
\text { which climate change and adaptation is } \\
\text { considered; iterative learning processes }\end{array}$ \\
\hline Integration & $\begin{array}{l}\text { Collaboration across sectors and stakeholders into } \\
\text { a coherent legislative, policy and decision- } \\
\text { making frameworks; incorporation of } \\
\text { uncertainty into decision-making }\end{array}$ \\
\hline
\end{tabular}

other variables allowed for (i.e. bridges) or blocked (i.e. barriers) the facilitation of adaptations (i.e. adaptive capacity) (Adger et al. 2009; Moser 2008) (see supplementary material for coding categories and logic). Similar themes are then identified as bridges as well as barriers between the case studies. It should be noted that for both studies, the identification of bridges and barriers is one element of a multi-pronged approach to investigate adaptation and adaptive capacity (Engle 2010; Hill 2013).

\section{Results}

Before discussing the most prominent bridges and barriers, it is important to highlight the major governance mechanisms that emerge (or are muted) in preparation for and response to the climate events analysed in this study. Table 3 presents the focussing events and the main governance mechanisms, which are then discussed for each case study area.

\section{Adaptive mechanisms in Valais, Switzerland}

To date, Valais has been more seriously impacted by extreme precipitation events and flooding than by situations of drought and water scarcity. Drought impacts were 
Fig. 1 Conceptual framework showing causal mechanism and methods

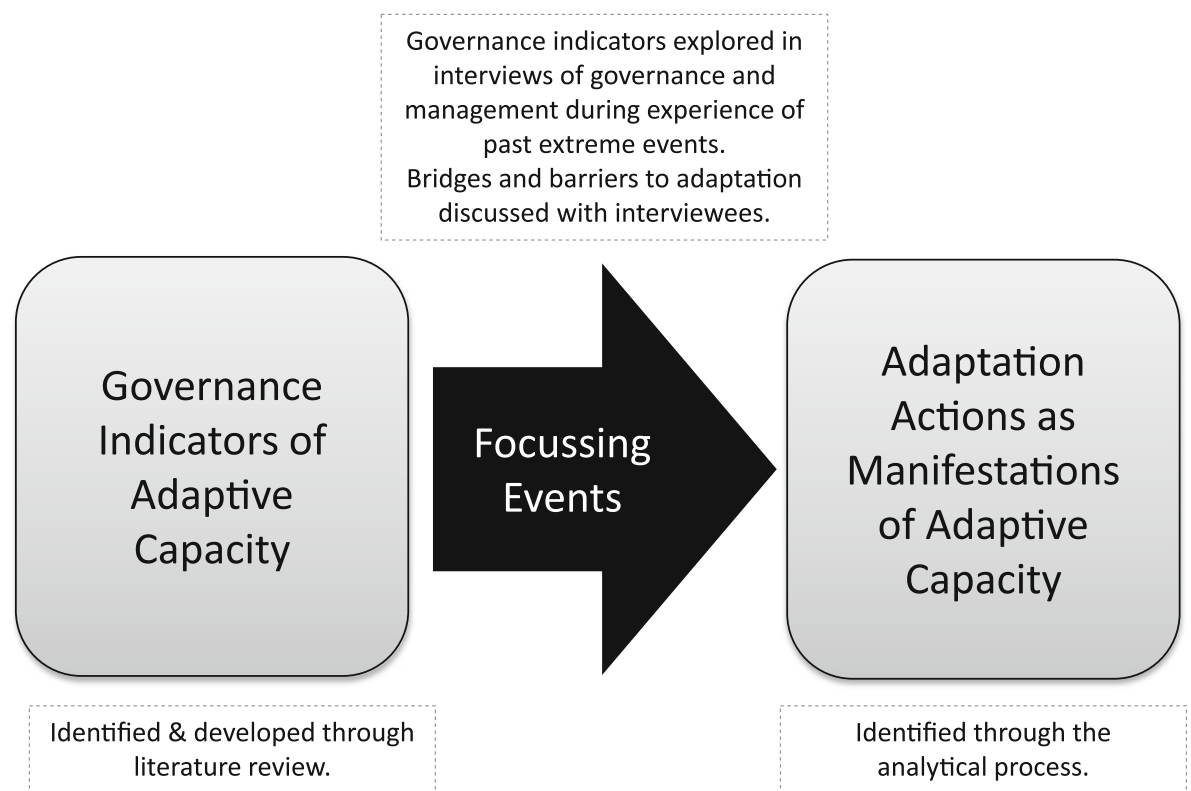

viewed by stakeholders as being relatively minor while extreme weather associated with high precipitation is seen as a much more significant issue. This has meant that stakeholders have generally been preparing for increased periods of flooding, and little effort has gone into assessing relevant measures for water stress.

Climate change is explicitly addressed by the federal administrative and national bodies for environmental and water issues in both developing framework for a climate policy (FOEN 2012) and mainstreaming climate issues into flood and hazard management policy (FOEN 2011). This fosters cross-sector collaboration and learning, which helps to build integrated solutions to future challenges in hydropower, watershed management and water infrastructure management at federal and regional scales. However, changes in water availability from climate change (as snow lines elevate and glacier contribution diminishes) tend to be perceived as a problem for the next generation rather than an urgent issue to be dealt with now. Many adaptation actions concerning water demand (e.g. ad hoc directives and use transfers for snow making) are quite reactive (i.e. responses during or after event to minimise short- and long-term damage from specific events). Furthermore, the decentralised governance and sovereignty of water at the local level has limited the canton's ability to implement a more basin-wide plan.

Following a series of extreme flooding events, an increasing number of collaborative and iterative sciencedriven projects were initiated in the hydropower sector as well as in flood management. MINERVE is a public-private partnership between Canton Valais, a federal university, Météosuisse, and hydropower companies to improve the modelling of and response network for extreme events, leading to enhanced reactive capacity. The canton and federal governments are developing the Third Rhone Correction (TRC) to proactively (i.e. mechanisms that represent longer-term processes to potential hydroclimatic stresses and events) increase the resilience of the socialecological system in the face of higher flooding uncertainties under climate change. It integrates climate change projections and introduces the concept of 'residual risk' (i.e. climate-change-based uncertainty) into the iterative implementation plan in order to incorporate the risk of a 1 in 100 years flood occurrence.

\section{Adaptive mechanisms in Georgia, USA}

In Georgia, community water systems (CWSs) are important for delivering water and maintaining lifestyles and livelihoods. The 'regulated riparian' governance approach helps coordination and consistency between upstream and downstream users, and the state oversight role can provide flexibility in times of water stress. National drought management coordination is sparse in the USA, leaving responsibility with states and local governments. Until recently, Georgia had prioritised responding to rather than preparing for severe droughts. The reactive approach has led to reduced self-reliance, fewer incentives for preparedness, a lack of coordination across institutions and sectors, and a crisis management mentality. Georgia has made some progress over the past decade to more proactively pursue cross-scale 'drought preparedness' efforts (e.g. the development and implementation of the 2003 State Drought Management Plan) (Georgia 2003). However, the 2007-2009 drought highlights the dominant role that the state plays in managing droughts. In 2007, the 
Table 3 Main Adaptive Mechanisms

\begin{tabular}{ll}
\hline Case study & Focussing events \\
\hline Canton Valais, & $\begin{array}{l}\text { Flooding events (1993 and 2000) and periodic } \\
\text { Switzerland }\end{array}$ \\
& $\begin{array}{l}\text { scarcity (e.g. 2003). Recession of glaciers, changes } \\
\text { in seasonality, melting of permafrost, and changes } \\
\text { in vegation and precipitation. Periods of low } \\
\text { precipitation and heat waves have so far been } \\
\text { offset with increased glacier meltwater }\end{array}$
\end{tabular}

Georgia, USA
Adaptive mechanisms

MINERVE is a public-private partnership to improve the modelling and response network to enhance its speed and efficacy to extreme precipitation events

Ad hoc local actions and user groups managed through private contracts and agreements to periodically transfer water to other stakeholders/uses (e.g. for artificial snow making). Commune directives are also issued to reduce water use in periods of drought

Third Rhone Correction (TRC) is supported by federal and cantonal laws on management of water courses; it is a major project to reinforce flood security in the Rhone valley, with a number of subobjectives to enhance social, ecological and economic security and well-being

Inter-commune contracts and agreements consolidate more communes into shared water utility service provision to better manage periods of high demand or scarcity by spreading water reserves across hydrologically diverse communes

State-declared drought emergency leads to one-size-fits-all conservation and curtailment in local communities

HB 1281 (2008) disallows local water systems from exceeding state levels of water restrictions and predrought strategies, limiting local drought management leadership and responsibilities

2003 Georgia Drought Management Plan (GDMP), innovative at the time, it was created in response to the early 1998-2002 drought. However, it is not regularly updated, has not been codified and is not necessarily followed during droughts

Metropolitan North Georgia Water Planning District (MNGWPD) creates water policies and plans on a regional/ intergovernmental basis ( 15 counties and $90+$ cities)

2008 Comprehensive Statewide Water Management Plan (SWP) process guides future water development, conservation and permitting decisions within the state and 11 regions (MNGWPD plus 10 others) along county lines with an attempt to follow watershed/groundwater basin boundaries (the process was since completed in 2011) governor declared a drought emergency, during which localities were required to follow broad-stroke conservation measures that did not take local conditions and needs into consideration. Moreover, legislation that was passed in 2008 actually restricted CWS managers from implementing locally specific drought response plans that were more stringent than the state's broad-stroke measures.

Climate change work in the legislative and executive branches is minimal in Georgia, due mainly to scepticism, but some state officials are gradually beginning to understand the impacts of climate change on water and drought planning. Moreover, CWS managers point to an increase in climate information use during the extreme drought period, although this information use decreased when the drought subsided. The Southeast, including Georgia, has a federally supported Regional Integrated Sciences and Assessments
(RISA) programme that produces climate change information and knowledge for various stakeholders. However, during the 2007-2009 drought event, the RISA had not yet developed an emphasis on climate information specifically for the water sector.

Information exchange and knowledge networks are supported through a combination of professional society activities and state-mandated efforts, such as the Metropolitan North Georgia Water Planning District (MNGWPD) and the Georgia Comprehensive State-wide Water Management Plan (SWP). Together, these state-led efforts are integrating resources, information and planning on a regional or intergovernmental basis and will guide future water development, conservation and permitting decisions within the state. This effort, if sustained, could prove essential for building proactive adaptive capacity. 
Common bridges for building adaptive capacity across the case studies

Despite the cases being highly varied from both a physical and institutional perspective, similar underlying challenges in developing (proactive adaptive capacity) and mobilising (reactive adaptive capacity) responses played out in these different contexts. The following section presents an overview of the core types of bridges and barriers to building and mobilising adaptive capacity that emerge and a description of how they manifest across the case areas.

\section{Trust and actor relationships}

In Georgia, staff dynamics and key relationships between those involved in the allocation of water supply and management of water resources help facilitate and improve the success rate of local inter-agency committees and collaboration. This is very important for developing networks and keeping the lines of communication and information flowing during times of crisis. In Valais, strong ties between individuals and close working relationships between local and cantonal levels provide a base for valuable support networks across subcanton and commune levels, particularly for the communication of hydrological information, training and maintenance of both institutional and built infrastructure.

\section{Regional collaboration and partnerships}

Formal regional organisations and initiatives are important bridges in Georgia. For example, the Georgia Association of Water Professionals (GAWP) and Association of Metropolitan Water Agencies provide avenues for local cross-community coordination, and the MNGWPD has increased evaluation and planning efforts considerably amongst CWS in the region. Stakeholders in the Valais case cite the importance of information networks in developing their understanding of the challenges and solutions to climate change impacts. Cross-level partnerships between federal, cantonal and local agencies collaborate with federal universities and research institutes to develop predictive modelling to inform adaptation evaluation and planning decisions. This has been vital to coordinate information and interpret data concerning extreme events for monitoring across emergency crisis groups at the canton and commune levels.

\section{Leadership}

Leadership is an extremely important bridge for Georgia. For example, in 2007, political officials indicated that reservoirs may be the future to solve Georgia's water problems (even though the physical ability to site additional reservoirs is limited, and such measures are likely short- to medium-term solutions for the state). Local CWS managers recalled hearing the same message during water scarce years in the 1980s. During that period, some local leaders had then had the foresight to pursue and build reservoirs, which subsequently helped secure water resources during the recent drought. In Switzerland in general, non-state actors have a high level of agency, due to the legal provision for the right of appeal for interested civil society and environmental organisations to challenge decisions in court (Art. 55, Federal Law on the Protection of the Environment 1983). This enables environmental groups to play a crucial leadership role in developing the federal water legislative and policy framework. This has in turn led to increased integration of longer-term ecological and climate-related issues.

\section{Regulatory and legislative}

Most Georgia CWSs acknowledge that the MNGWPD and recent SWP processes have improved adaptive capacity by requiring regional evaluation and planning and improving water conservation efforts through communication and information. Interviews also show that this bridge is particularly helpful in building adaptive capacity when CWS anticipates that regulations are forthcoming, and managers work proactively with the community to collaborate and solve potential problems that might arise. In Valais, federal and cantonal provisions on the duty for ecological integration in spatial planning and integrated flood management are driving forces behind most adaptive elements of the TRC.

Common barriers for building adaptive capacity across the case studies

\section{Political}

Political barriers prevail in Georgia, as many CWSs refer to the over 20-year interstate water conflict with Alabama and Florida as hindering their ability to implement certain approaches, such as increasing supply infrastructure. Another political barrier includes lobbying efforts by certain industries to loosen water restrictions placed upon them during the droughts. Many Georgia CWSs interpret such lobbying as undermining hard-earned gains from recent long-term planning and evaluation approaches, which ultimately undercuts overall adaptive capacity. In Valais, the limited authority of the federal government combined with resistance and aversion to federal intervention at lower levels weakens the enforcement of federal legal provisions and policy guidelines for longer-term 
policies and plans that integrate climate and broader ecological concerns.

\section{Regulatory and legislative}

This category represents a double-edged sword for building adaptive capacity in Georgia, because it manifests as both a bridge and a barrier. While the state plays a significant regulatory role in facilitating adaptations through required participation in regional planning processes, some local water systems interpret certain state actions as significant constraints for adaptive capacity building. For instance, legislation passed in 2008 precludes CWS from implementing water-use restrictions that are stricter than those determined by the state. Other required measures are not encouraged or enforced by the state in practice (e.g. local drought contingency planning), leaving many local CWS confused as to how to proceed in preparing for and responding to droughts. In Valais, where run-off is relatively abundant, there is currently no legislative or policy guidance on managing water resources at the watershed level, and rules or ordinances for managing conflicts and scarcity are only rudimentary. This is seen to lead to a lack of planning for coping potential changes in water availability from climate change impacts on snow and ice.

\section{Perception and cognitive}

In Georgia, CWS perceives that it is the state's responsibility to plan for future water, negating their own need and responsibility to implement certain management approaches, such as the use of climate information. Furthermore, perception and cognitive barriers cause many CWSs in Georgia to question why longer-term planning and evaluation is useful, since they have only experienced abundant amounts of rainfall in their lifetimes, with droughts typically lasting a maximum of 3 years. Similarly, in Valais, despite high climate change awareness, the perception of Valais as a water tower of Europe is linked with a sense of apathy towards longer-term planning for climate change impacts.

\section{Discussion}

As noted earlier, identification of the major bridges and barriers to adaptation allows us to provide more empirically informed connections between governance indicators and adaptive capacity. This section draws on the case evidence to provide a more nuanced understanding of the governance indicators listed in Table 1. It presents examples of case evidence that supports their role in enhancing adaptive capacity and highlights some of the challenges associated.
Networks between stakeholders (personal, formal and informal), which include conflict resolution mechanisms, encourage cooperation, learning and involvement, are important. Such networks help to bolster not only the adaptive capacity of specific locales, but also that of broader regional scales. For example, in Valais, regional, sectoral and scientific networks play an important role in generating knowledge and creating different fora for actors to exchange experiences on common issues and solutions. This helps to bridge the gap created by the level of decentralisation and strong local autonomy.

Flexibility is clearly an important component of adaptive capacity, but our findings more precisely indicate the importance of instilling flexibility in the plans and approaches for managing hydroclimatic events as well as in the triggers that define the start and end of a particular event (and that are iteratively updated to reflect the best available science). During the recent drought events in Georgia, local flexibility that could have facilitated adaptive capacity was sacrificed by broad-stroke state-determined responses. Not only did drought responses therefore not benefit from local expertise, but the top-down approach disallowed local responses from being more stringent than those declared by the state.

Knowledge provision with stakeholders helps build understanding and awareness of changing conditions into clear implications for various interests. Evaluation and planning, itself reliant on monitoring networks and data (including monitoring of social, infrastructural and ecological components of a system before, during and after an event), is also seen to foster and enable preparedness, which is critical for navigating bridges and barriers. It is most effective when it begins at local levels, with local autonomy balanced by a mix of regulation, subsidies and incentivisation tools from higher levels. For example, in Valais, and in Switzerland in general, data provision between national monitoring networks, canton authorities and private hydropower companies is crucial to the safe management of flooding episodes and connects expertise from local to federal levels. Furthermore, local autonomy drives the need for both cantonal and federal authorities to explain the rational behind water management decisions and projects. Despite requiring significant investments in time and money, this means that a process of consensus building fosters gradual acceptance and agreement on water management strategies.

Integration, especially of multiple informational sources, links managers at regional and local levels and across different sectors through monitoring and assessment efforts, informal study groups and other initiatives perceived to foster consensus and collaboration to tackle climate-related challenges. For example, in Georgia there are relatively strong ties and information exchange through professional organisations and the MNGWPD and SWP. 
Still, there is ample opportunity to improve the integration of monitoring and assessment through the RISA by focussing it more intently on the water sector and water resources stakeholders.

The investigation of bridges and barriers in relation to the different adaptive capacity governance indicators provides some ground for deciphering the relative importance of these governance assumptions in different cases. Networks and integration, particularly trust across different actors and networks, emerged as a dominant theme. These factors play an important role in balancing interests at different governance levels in order to build cooperation for more complex challenges in relation to climatic uncertainty and extremes.

Furthermore, while some of the principles, such as networks and integration, can be seen as self-reinforcing in reducing barriers and bolstering bridges, others might be counteractive in certain cases. For instance, flexibility and evaluation and planning at different levels of decision-making can ultimately be in conflict with one another. Sometimes rigidity is needed from higher scales to help guide the processes that build adaptive capacity (e.g. state requirements for drought preparedness planning at the local level) (Hill and Engle 2013). On the other hand, resources (financial, technical, human), policies for and commitments to enhance networks through better communication and information transfer would enable more integrated evaluation and planning, and thus adaptive capacity. These are only a handful of the issues that more empirical analyses in relation to actual extreme events can offer to better understand the governance factors assumed to increase adaptive capacity.

These lessons are also applicable to DRR challenges specific to the increase in the frequency or intensity of climate-related hazards (e.g. floods, storms, droughts and landslides) (ECB 2013). In particular, improving integration between short- and long-term planning and enhancing trust building across different governance scales and sectors is crucial to aligning adaptation and risk resilience priorities. For example, both flood and water resources management could focus on multiple benefits from integrated reservoir management (integrating requirements across hydropower, conservation and water supply sectors) to minimise the impacts of drought and flooding events. Integrated flood management policy could prioritise flexibility through riparian buffer zones (trade-offs across conservation, agriculture and adaptation requirements) to restore vital freshwater ecosystems and provide future protection against more extreme flood events.

\section{Conclusion}

This paper has highlighted a number of common lessons on the challenges and possibilities of building adaptive capacity elicited from a set of contrasting case studies, which both fall within a federal governance system. Evidence from the state of Georgia reveals challenges relating to a lack of leadership and planning for climate change impacts in the legislative and executive branches (related to climate scepticism). Alternatively, in Canton Valais there is more proactive preparation for flooding events (though not for water management issues relating to water stress periods and changing availability) in part due to the more explicit focus on climate change within federal policy frameworks. A key differentiator between the two cases is the level of state oversight. In Georgia, water managers are seen to constrict locally appropriate responses, while in Valais, although there is more autonomy to implement locally specific water management actions, challenges persist in forming and implementing more integrated water management planning across the canton. In both cases, challenges arise from a lack of coordination between institutions and sectors, while information and knowledge exchange networks at regional and sector levels are vital for developing regional collaboration and partnerships to address water-related challenges.

The paper therefore presents an empirical approach to understanding the bridges and barriers to adaptation in the context of a set of governance arrangements and principles that previous research has assumed to increase adaptive capacity. The bridge and barrier analysis can be combined with other means of assessing adaptive capacity within governance systems (e.g. indicator assessments), in order to converge on more robust understanding of criteria that lead to more resilient outcomes. This analysis shows that there is no one governance arrangement that is most conducive to building adaptive capacity. However, despite the difference in governance contexts and variety of climatic events across case studies, the bridge and barrier analysis does uncover a number of common themes and more nuanced insights.

From an operational perspective, recognition of the bridge and barrier themes that emerge from this cross-case water governance comparison (i.e. trust and actor relationship, regional collaboration and partnerships, leadership, and regulatory and legislative bridges, and political, regulatory and legislative, perception and cognitive barriers) could help decision-makers to implement actions to ensure adaptive responses at one scale (local/regional, climate variability/climate change, across sectors) do not degrade the ability to respond to challenges or risks at another scale.

From a theoretical perspective, analysis of bridges and barriers across these governance principles supports evidence from other studies of potential conflicts between the premise of adaptive and integrative water governance and management techniques and their practical relevance 
(Bierbaum et al. 2012; Medema et al. 2008). While these findings would certainly be bolstered by further case evidence, the commonality in bridge and barrier themes across these two cases (in terms of climate stress, demographics and socio-economic context) suggests that focussing on these themes is a good place to start.

Acknowledgments The authors would like to acknowledge all those who took the time to be interviewed for this research and those who were of great help in setting up successful field trips to the case areas. The work presented from Switzerland was supported by the ACQWA project, coordinated by the University of Geneva under EC contract 212250, and the US work was supported by the Dan David Prize Fellowship and the University of Michigan.

\section{References}

Adger WN, Arnell NW, Tompkins E (2005) Successful adaptation to climate change across scales. Glob Environ Chang 15:77-86. doi:10.1016/j.gloenvcha.2004.12.005

Adger WN, Agrawala S, Mirza MMQ, Conde C, O'Brien K, Pulhin J, Pulwarty R, Smit B, Takahashi K (2007) Assessment of adaptation practices, options, constraints and capacity. In: Parry ML, Canziani OF, Palutikof JP, van der Linden PJ, Hanson CE (eds) Climate change 2007: impacts, adaptation and vulnerability. Contribution of working group II to the fourth assessment report of the intergovernmental panel on climate change. Cambridge University Press, Cambridge

Adger WN, Dessai S, Goulden M, Hulme M, Lorenzoni I, Nellson DR, Naess LO, Wolf J, Wreford A (2009) Are there social limits to adaptation to climate change? Clim Chang 93:335-354. doi:10.1007/s10584-008-9520-z

Adger WN, Brown K, Nelson DR, Berkes F, Eakin H, Folke C, Galvin K, Gunderson L, Goulden M, O'Brien K, Ruitenbeek J, Tompkins EL (2011) Resilience implications of policy responses to climate change. WIREs Clim Chang 2:757-766. doi:10.1002/ Wcc. 133

Adhikari B, Taylor K (2012) Vulnerability and adaptation to climate change: a review of local actions and national policy response. Clim Dev 4:54-65. doi:10.1080/17565529.2012.664958

Bierbaum R, Smith JB, Lee A, Blair M, Carter L, Chapin FS, Fleming P, Ruffo S, Stults M, McNeeley S, Wasley E, Verduzco L (2012) A comprehensive review of climate adaptation in the United States: more than before, but less than needed. Mitig Adapt Strat Glob Change. doi:10.1007/s11027-012-9423-1

Brooks N, Adger WN (2005) Assessing and enhancing adaptive capacity. In: Lim B, Spanger-Siegfried E (eds) Adaptation policy frameworks for climate change: developing strategies, policies and measures. UNDP-GEF, pp 165-181

Brooks N, Adger WN, Kelly PM (2005) The determinants of vulnerability and adaptive capacity at the national level and the implications for adaptation. Glob Environ Chang 15(2):151-163. doi:10.1016/j.gloenvcha.2004.12.006

Chapin FS, Kofinas GP, Folke C (2009a) Principles of ecosystem stewardship: resilience-based natural resource management in a changing world. Springer, Berlin

Chapin FS, Folke C, Kofinas GP (2009b) A framework for understanding change. In: Chapin FS, Kofinas GP, Folke C (eds) Principles of ecosystem stewardship resilience-based natural resource management in a changing world. Springer, New York
Crabbé P, Robin M (2006) Institutional adaptation of water resource infrastructures to climate change in eastern Ontario. Clim Chang $78: 103-133$

ECB (2013) Toward resilience: a guide to disaster risk reduction and climate change adaptation. Emergency capacity building project, Available at: http://www.ecbproject.org/downloads/ECB-towardresilience-Disaster-risk-reduction-Climate-Change-Adaptationguide-english.pdf

Ekstrom JA, Moser SC, Torn M (2011) Barriers to adaptation: a diagnostic framework, PIER Research Report CEC-500-2011004. Public Interest Energy Research, Sacramento

Engle NL (2010) Adaptation to extreme droughts in Arizona, Georgia, and South Carolina: evaluating adaptive capacity and innovative planning and management approaches for states and their community water systems. University of Michigan, Ann Arbor

Engle NL (2011) Adaptive capacity and its assessment. Glob Environ Chang 21:647-656. doi:10.1016/j.gloenvcha.2011.01.019

Engle NL, Lemos MC (2010) Unpacking governance: building adaptive capacity to climate change of river basins in Brazil. Glob Environ Chang 20:4-13. doi:10.1016/j.gloenvcha.2009.07.001

Federal Law on the Protection of the Environment (1983) Bundesgesetz über den Umweltschutz (USG), SR 814.01. www.admin. $\mathrm{ch} / \mathrm{ch} / \mathrm{d} / \mathrm{sr} / \mathrm{c} 814$ _01.html, 7 Oct 1983 (Status on 1 Aug 2010)

FOEN (2011) Leben mit Naturgefahren: Ziele und Handlungsschwerpunkte des Bundesamts für Umwelt (BAFU) im Umgang mit Naturgefahren. Federal Office for the Environment: Natural Hazards Prevention Division, Bern

FOEN (2012) Adaptation to climate change in Switzerland-goals, challenges and fields of action. Federal Office for the Environment, Bern

Folke C, Hahn T, Olsson P, Norberg J (2005) Adaptive governance of social-ecological systems. Annu Rev Environ Resour 30:441-473. doi:10.1146/annurev.energy.30.050504.144511

Gaillard JC, Mercer J (2013) From knowledge to action: bridging gaps in disaster risk reduction. Prog Hum Geogr 37:93-114. doi:10.1177/0309132512446717

Garmestani AS, Allen CR, Cabezas H (2009) Panarchy, adaptive management and governance: policy options for building resilience. Neb Law Rev 87:1036-1054

Georgia (2003) Georgia drought management plan. Georgia Department of Natural Resources Board, Available at: http://www. gaepd.org/Files_PDF/gaenviron/drought/drought_mgmtplan_ 2003.pdf. Accessed 15 Aug 2009

Gupta J, Termeer C, Klostermann J, Meijerink S, Van den Brink M, Jong P, Nooteboom S, Bergsma E (2010) The adaptive capacity wheel: a method to assess the inherent characteristics of institutions to enable the adaptive capacity of society. Environ Sci Policy 13:459-471. doi:10.1016/j.envsci.2010.05.006

Hill M (2011) Characterising adaptive capacity in water governance arrangements in the context of extreme events. In: Leal Filho W (ed) Climate change and the sustainable use of water resource. Springer, Berlin, pp 339-366

Hill M (2013) Climate change and water governance: adaptive capacity in Chile and Switzerland. Springer, Heidelberg

Hill M, Engle NL (2013) Adaptive capacity: tensions across scales. Environ Policy Gov 23:177-192. doi:10.1002/eet.1610

Huntjens P, Pahl-Wostl C, Rihoux B, Schlüter M, Flachner Z, Neto S, Koskova R, Dickens C, Nabide Kiti I (2011) Adaptive water management and policy learning in a changing climate: a formal comparative analysis of eight water management regimes in Europe, Africa and Asia. Environ Policy Gov 21:145-163. doi:10.1002/eet.571

Jewitt G (2002) Can integrated water resources management sustain the provision of ecosystem goods and services? Phys Chem Earth 27:887-895 
Matthews JH, Wickel BAJ, Freeman S (2011) Converging currents in climate-relevant conservation: water, infrastructure, and institutions. PLoS Biol 9:e1001159. doi:10.1371/journal.pbio.1001159

Medema W, McIntosh BS, Jeffrey PJ (2008) From premise to practice: a critical assessment of integrated water resources management and adaptive management approaches in the water sector. Ecol Soc 13:29 [online]. http://www.ecologyandsociety. org/vol13/iss22/art29/

Milly PCD, Betancourt J, Falkenmark M, Hirsch RM, Kundzewicz ZW, Lettenmaier DP, Stouffer RJ (2008) Stationarity is dead: whither water management? Science 319:573-574. doi:10.1126/ science. 1151915

Moser SC. (2008) Resilience in the face of global environmental change. Community and Regional Resilience Initiative (CARRI). Research Report 2, Oak Ridge National Laboratory, Tennessee

Moser S, Eckstrom J (2010) A framework to diagnose barriers to climate change adaptation. Proceedings of National Academy of Sciences of the United States of America www.pnas.org/cgi/doi/ 10.1073/pnas.1007887107

Nelson DR, Adger WN, Brown K (2007) Adaptation to environmental change: contributions of a resilience framework. Annu Rev Environ Resour 32:395-419. doi:10.1146/annurev.energy.32. 051807.090348

Pahl-Wostl C (2007) Requirements for adaptive water management. In: Pahl-Wostl C, Kabat P, Möltgen J (eds) Adaptive and integrated water management. Coping with complexity and uncertainty. Springer, Berlin
Pahl-Wostl C (2009) A conceptual framework for analysing adaptive capacity and multi-level learning processes in resource governance regimes. Glob Environ Chang Human Policy Dimens 19:354-365. doi:10.1016/j.gloenvcha.2009.06.001

Pahl-Wostl C, Kabat P, Möltgen J (2007) Adaptive and integrated water management. Coping with complexity and uncertainty. Springer, Berlin, p 440

Pahl-Wostl C, Sendzimir J, Jeffrey P (2009) Resources management in transition. Ecol Soc 14:46. [online] url: http://www. ecologyandsociety.org/vol14/iss41/art46/

Seng DSC (2013) Tsunami resilience: multi-level institutional arrangements, architectures and system of governance for disaster risk preparedness in Indonesia. Environ Sci Policy 29:57-70. doi:10.1016/j.envsci.2012.12.009

Smit B, Wandel J (2006) Adaptation, adaptive capacity and vulnerability. Glob Environ Chang 16:282-292. doi:10.1016/j. gloenvcha.2006.03.008

Tompkins EL, Lemos MC, Boyd E (2008) A less disastrous disaster: managing response to climate-driven hazards in the Cayman Islands and NE Brazil. Glob Environ Chang 18:736-745

UNDP (1997) Governance for Sustainable Human Development. United Nations Development Programme. Online: http://mirror. undp.org/magnet/policy/

Wright KR; AWWA Water Rights Allocation Committee (1998) Water rights of the eastern United States. American Water Works Association, Denver 